Journal of Applied Pharmaceutical Science Vol. 7 (01), pp. 051-056, January, 2017

Available online at http://www.japsonline.com

DOI: 10.7324/JAPS.2017.70107

ISSN 2231-3354 (cc) BY-NC-SA

\title{
Modulatory effects of Aqueous extract from Tetracarpidium conophorum leaves on key enzymes linked to erectile dysfunction and oxidative stress-induced lipid peroxidation in penile and testicular
} tissues

\author{
Seun Akomolafe ${ }^{1}$, Ganiyu Oboh $^{2}$, Tosin Olasehinde ${ }^{3 *}$, Sunday Oyeleye ${ }^{2,4}$, Opeyemi Ogunsuyi ${ }^{2,4}$ \\ ${ }^{1}$ Department of Biochemistry, Ekiti State University, P.M.B 5363 Ado Ekiti, Nigeria. \\ ${ }^{2}$ Functional foods and Nutraceuticals Unit, Department of Biochemistry, Federal University of Technology, PMB 704 Akure, Nigeria. \\ ${ }^{3}$ Nutrition and Toxicology Division, Food Technology Department, Federal Institute of Industrial Research, Oshodi, PMB 21023, Lagos 10001, Nigeria. \\ ${ }^{4}$ Department of Biomedical Technology, Federal University of Technology Akure, PMB 704, Akure, Nigeria .
}

\section{ARTICLE INFO}

Article history:

Received on: 14/03/2016

Revised on: 23/05/2016

Accepted on: 11/06/2016

Available online: 31/01/2017

\section{Key words:}

Tetracarpidium conophorum; erectile dysfunction; arginase; angiotensin-I converting enzyme, acetylcholinesterase.

\begin{abstract}
Tetracarpidium conophorum (walnut) is used in folk medicine for the treatment of erectile dysfunction but the mechanism remains unclear. This study evaluated the effect of aqueous extract from $T$. conophorum leaves on oxidative stress-induced penile damage and key enzymes linked to erectile dysfunction. The inhibitory effect of the extract on sodium nitroprusside (SNP)-induced lipid peroxidation, arginase, angiotensin I-converting enzyme (ACE) and acetylcholinesterase (AChE) activities in penile and testicular tissue homogenates were determined via colorimetric method. The aqueous extract inhibited SNP-induced lipid peroxidation in rats penile and testicular homogenates in a dose dependent manner. The highest inhibitory effect was obtained in the penis at a concentration of $0.5 \mathrm{mg} / \mathrm{mL}$. Furthermore, the extract inhibited arginase activity in a dose dependent pattern. The $\mathrm{IC}_{50}$ revealed that the extract had significantly $(\mathrm{P}<0.05)$ higher inhibitory activity in the penile tissue $(130.96 \mu \mathrm{g} / \mathrm{mL})$ than the testicular tissue $(179.02 \mu \mathrm{g} / \mathrm{mL})$ homogenate. However, the AChE inhibitory activity of the extract was significantly $(\mathrm{P}<0.05)$ higher in the testes $(0.47 \mathrm{mg} / \mathrm{mL})$ when compared to the penis $(0.58$ $\mathrm{mg} / \mathrm{mL}$ ). Similarly, the activity of ACE was reduced by the extract. A higher inhibitory activity was observed in the testes $(114.21 \mu \mathrm{g} / \mathrm{mL})$ than the penis $(127.71 \mu \mathrm{g} / \mathrm{mL})$. The observed inhibitory activities could be linked with the phenolic compounds present in the extract and this could further justify the use of $T$. conophorum leaves for the treatment of ED.
\end{abstract}

\section{INTRODUCTION}

Penile erection is a neurovascular event which depends on neural integrity, functional vascular system, and healthy cavernosal tissue (Bivalacqua et al., 2003). The erection process involves relaxation of the corpus cavernosum smooth mucles and vasodilation of the arterioles in the penis (Kandeel et al., 2001). This induces the pressure of blood flow and expansion of the

\footnotetext{
* Corresponding Author

Tosin Olasehinde, Nutrition and Toxicology Division, Food Technology Department, Federal Institute of Industrial Research, Oshodi, PMB

21023, Lagos 10001, Nigeria. Email: tosinolasehinde26 @ yahoo.com
}

sinusoidal spaces of the tissue which enlarges the penis. Previous experimental investigations have shown that some pathological alterations in the penile vasculature may trigger the impairment of the erection process which leads to the development of erectile dysfunction (ED) (Andersson, 2003; Bivalacqua et al., 2003). Free radical induced alteration of penile vasculature and oxidative damage to the carvenosal tissues are major risk factors which are responsible for the pathogenesis of ED (Jeremy et al., 2000). NO has been implicated as a mediator of penile erection (Jung et al., 2014).

However, reaction of NO with superoxide anion leads to the production of peroxynitrites which reduces the bioavailability of endothelial and neuronal NO (Darley-Usmar and White, 1997). 
Overproduction of peroxynitrites may induce oxidative damage and degeneration of nerve cells in the penile tissues which may impair the erectile process (Ferrini et al., 2001). Furthermore, up-regulation of some enzymes such as arginase, acetylcholinesterase and angiotensin-I converting enzyme which are responsible for normal physiological processes in the penile and testicular vasculature could lead to ED via different mechanisms such as endothelial dysfunction, impairment of NO/cGMP pathway, smooth muscle dysfunction and neurodegeneration (Andersson, 2011). However, inhibition of these enzymes could improve erectile function and serve as a therapeutic strategy for the treatment of ED.

Moreover, synthetic drugs have been developed for the treatment of vascular disorders associated with impaired endothelial cell function and ED (Subhashini et al., 2011). Recent trends in reproductive research involves a search for a novel agent that is effective, cheap and easily accessible due to the side effects and efficacy levels of synthetic drugs.

Tetracarpidium conophorum (Mull. Arg) Hutch \& Dalziel commonly called African walnut is a climbing shrub in the family Euphorbiaceae (Akomolafe et al., 2015). It is locally cultivated mainly for the nuts and is considered to be a tonic and aphrodisiac. The leaves and fruit of the plant are used in folklore medicine for the treatment of giddiness, toothache, eczema, pruritus, psoriasis, common cold, prostate cancer and dysentery (Odugbemi and Akinsulire 2008). The use of T. conophorum leaves for the treatment of male sexual dysfunction has been reported (Odugbemi and Akinsulire, 2008; Akomolafe et al., 2015). However, to the best of our knowledge there is little or no information on the possible mechanism of action of $T$. conophorum on penile function. This study was designed to investigate the inhibitory effects of aqueous extract from $T$. conophorum leaves on enzymes linked to ED (angiotensin-1 converting enzyme $[\mathrm{ACE}]$, acetylcholinesterase $[\mathrm{AChE}]$ and arginase) and sodium nitroprusside-induced lipid peroxidation in rats' penile and testicular tissue homogenates in vitro.

\section{MATERIALS AND METHODS}

\section{Collection and identification of sample}

Fresh samples of $T$. conophorum leaves were obtained from a farm land near Akure metropolis, Nigeria during wet season around July and August. Authentication of the sample was carried out at the Department of Plant Science, Ekiti State University by Mr Ajayi and voucher specimen (number UHAE 335) was deposited in the herbarium of the Department.

\section{Preparation of Aqueous Extract}

The leaves were air dried, homogenized and kept dry in an air-tight container prior to the extraction. The plant material (50 g) was soaked in $1 \mathrm{~L}$ of cold distilled water for 24 hours. The mixture was then filtered through Whatman No. 1 filter paper and the filtrate centrifuged at $805 \times \mathrm{g}$ for $10 \mathrm{~min}$. The clear supernatant collected was freeze dried and stored in small, capped plastic container at $4{ }^{\circ} \mathrm{C}$ until required. The plant yield was $12.5 \mathrm{~g}$ dry powder $/ 50 \mathrm{~g}$ powdered leaf. This was later reconstituted in water for subsequent analysis.

\section{Experimental animals}

Twenty male Wistar albino rats weighing between 190 and $250 \mathrm{~g}$ were purchased from the Central Animal House, Department of Biochemistry, University of Ilorin, Nigeria. They were housed in stainless steel cages under controlled conditions of a $12 \mathrm{~h} \mathrm{light/dark} \mathrm{cycle} \mathrm{at} \mathrm{room} \mathrm{temperature.} \mathrm{The} \mathrm{rats} \mathrm{were} \mathrm{allowed}$ asses to food and water ad libitum. This study was carried out with approval from the ethics committee on the use and care of experimental animals at the Department of Biochemistry, Federal University of Technology, Akure, Nigeria. The research also adhered strictly to the Principles of Laboratory and Animal Care (NIH Publication, No. 85-23).

\section{Chemicals and reagents}

Chemicals and reagents such as malondialdehyde tetrabutyl ammonium salt (standard MDA), thiobarbituric acid (TBA), trichloroacetic acid, acetic acid and 5,5'-dithio-bis (2nitrobenzoic) acid (DTNB) were sourced from Sigma-Aldrich, Chemie GmbH (Steinheim, Germany), Erhlich reagent (pdimethylaminobenzaldehyde), Tris $\mathrm{HCL}, \mathrm{MnCl}_{2}$, Hippurylhistidylleucine substrate, acetylthiocholine iodide, sbutyrylthiocholine iodide and L-arginine were procured from Sigma-Aldrich, Inc., (St. Louis, MO, USA). Sodium dodecyl sulfate, $\mathrm{FeSO}_{4}$ and all other chemicals used were of analytical grade, while the water was glass distilled.

\section{Preparation of tissue homogenate}

The rat was decapitated under mild anesthesia (diethyl ether) and the tissues (penis and testes) were isolated and placed on ice and weighed. Each tissue was subsequently homogenized in cold saline $(1 / 10 \mathrm{w} / \mathrm{v})$ with about 10-up and-down strokes at approximately $1200 \mathrm{rev} / \mathrm{min}$ in a Teflon glass homogenizer. The homogenate was centrifuged for $10 \mathrm{~min}$ at $3000 \mathrm{~g}$. The pellets obtained were discarded while the supernatant was kept for lipid peroxidation assay (Belle et al., 2004)

\section{Lipid peroxidation and thiobarbibutric acid reactions}

The lipid peroxidation assay was carried out using the method of Botsoglou et al. (1994). Briefly, $100 \mu \mathrm{L}$ S1 fraction was mixed with a reaction mixture containing $30 \mu \mathrm{L}$ of $0.1 \mathrm{M}$ Tris$\mathrm{HCl}$ buffer ( $\mathrm{pH}$ 7.4), aqueous extract of $T$. conophorum leaves ( 0 $100 \mu \mathrm{L}$ ) and $30 \mu \mathrm{L}$ of $5 \mathrm{mM}$ freshly prepared sodium nitroprusside (SNP). The volume was made up to $300 \mu \mathrm{L}$ with water before incubation at $37^{\circ} \mathrm{C}$ for $1 \mathrm{~h}$. The color reaction was developed by adding $300 \mu \mathrm{L}$ of $8.1 \%$ SDS to the reaction mixture containing S1. This was subsequently followed by the addition of $500 \mu \mathrm{L}$ of acetic acid/ $\mathrm{HCl}(\mathrm{pH} 3.4)$ and $500 \mu \mathrm{L} 0.8 \%$ TBA. The mixture was incubated at $100^{\circ} \mathrm{C}$ for $1 \mathrm{~h}$. The absorbance of thiobarbituric acid reactive species produced was measured at $532 \mathrm{~nm}$. MDA produced was expressed in percentage (\%). 


\section{Arginase Inhibition Assay}

Arginase activity was determined by the measurement of urea produced by the reaction of Ehrlich's reagent according to the modified method of Aminlari (1992). Tissue lysate of the penis and testes were prepared using lysis buffer $(50 \mathrm{mM}$ Tris-HCL, $\mathrm{pH}$ $7.5,0.1 \mathrm{mM}$ EDTA) via homogenization at $4^{\circ} \mathrm{C}$ followed by centrifugation for $10 \mathrm{~min}$ at $3000 \mathrm{~g}$. Arginase activity was determined in a reaction mixture containing $50 \mu \mathrm{L}$ of each (penis and testes) tissue homogenate in $0.1 \mathrm{M}$ Tris- $\mathrm{HCl}$ buffer, $\mathrm{pH} 9.5$, sample $(0-100 \mu \mathrm{L})$ and $50 \mu \mathrm{L}$ of $0.1 \mathrm{M} \mathrm{L}$ - arginine solution as the substrate. After incubation for $10 \mathrm{~min}$ at $37^{\circ} \mathrm{C}$, Erhlich solution (pdimethylaminobenzaldehyde) (2500 $\mu \mathrm{L}$ of $2 \mathrm{~g} / 20 \mathrm{~mL}$ conc. HCL) was added, and this was allowed to stand for $20 \mathrm{~min}$. Arginase activity was determined by UV spectrophotometry at $550 \mathrm{~nm}$. The arginase activity was expressed as percentage inhibition.

\section{Acetylcholinesterase (AChE) Inhibition Assay}

The effect of the aqueous extract on acetylcholinesterase (AChE) activity was carried out using the colorimetric method of Tor et al (1994). The AChE activity was determined in a reaction mixture containing $200 \mu \mathrm{L}$ of each (penis and testes) tissue homogenate in $0.1 \mathrm{M}$ phosphate buffer, $\mathrm{pH} 8.0,100 \mu \mathrm{L}$ of a solution of 5,5'-dithio-bis (2- nitrobenzoic) acid (DTNB $3.3 \mathrm{mM}$ in $0.1 \mathrm{M}$ phosphate buffered solution, $\mathrm{pH} 7.0$, containing $\mathrm{NaHCO}_{3} 6$ $\mathrm{mM})$, sample $(0-100 \mu \mathrm{L})$ and $500 \mu \mathrm{L}$ of phosphate buffer, $\mathrm{pH}$ 8.0. After incubation for $20 \mathrm{~min}$ at $25^{\circ} \mathrm{C}$, acetylthiocholine iodide (100 $\mu \mathrm{L}$ of $0.05 \mathrm{mM}$ water solution) was added as the substrate, and AChE activity was determined by UV spectrophotometry from the absorbance changes at $412 \mathrm{~nm}$ for $3.0 \mathrm{~min}$ at $25^{\circ} \mathrm{C}$. The $\mathrm{AChE}$ activity was expressed as percentage relative activity.

\section{ACE inhibition assay}

The inhibition of ACE was determined by the method of Cushman and Cheung (1971). Appropriate dilutions of the extracts $(0-200 \mu \mathrm{L})$ and $50 \mu \mathrm{L}$ of each (penis and testes) tissue homogenate were incubated at $37^{\circ} \mathrm{C}$ for $15 \mathrm{~min}$. After preincubation, the enzymatic reaction was initiated by adding $150 \mu \mathrm{L}$ of $8.33 \mathrm{mM}$ Hippuryl-histidyl-leucine (Bz-Gly-His-Leu) in 125 $\mathrm{mM}$ Tris- $\mathrm{HCl}$ buffer $(\mathrm{pH} 8.3)$ to the mixture and incubating at $37^{\circ} \mathrm{C}$ for $30 \mathrm{~min}$. After incubation, the reaction was stopped by the addition $250 \mu \mathrm{L}$ of $1 \mathrm{M} \mathrm{HCl}$. The Gly-His bond was then cleaved and the hippuric acid produced by the reaction was extracted with $1.5 \mathrm{~mL}$ ethyl acetate. Thereafter, the mixture was centrifuged to separate the ethyl acetate layer; then $1 \mathrm{~mL}$ of the ethyl acetate layer was transferred to a clean test tube and evaporated. The residue was re-dissolved in distilled water and its absorbance was measured at $228 \mathrm{~nm}$. The control experiment was performed without the test sample and the ACE inhibitory activity was expressed as percentage inhibition:

$$
\% \text { Inhibition }=\left[\left(\mathrm{Abs}_{\text {Control }}-\mathrm{Abs}_{\text {Samples }}\right) / \mathrm{Abs}_{\text {Control }}\right] \mathrm{X} 100
$$

\section{Data analysis}

The result of three replicate experiments were pooled and expressed as mean \pm standard deviation (SD). Student $t$ - test was carried out to analyze the result. Significance was accepted at $P \leq$ 0.05 and $\mathrm{IC}_{50}$ (the concentration of extracts required to inhibit $50 \%$ of enzyme activity) was calculated using nonlinear regression analysis.

\section{RESULTS}

The effect of in vitro administration of aqueous extract from $T$. conophorum leaves on malondialdehyde accumulation in rats' penile and testicular homogenates are presented in Figure 1.

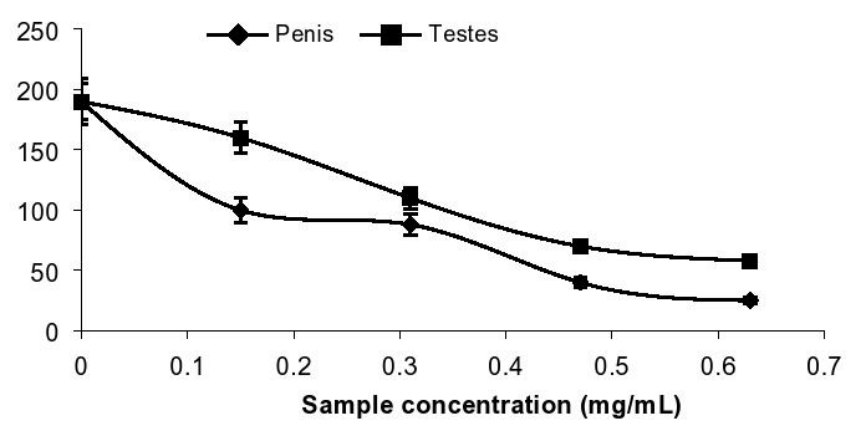

Fig. 1: Inhibition of SNP -induced lipid peroxidation in rats' genitals homogenates by aqueous extract from Tetracarpidium conophorum leaves. $\mathrm{n}=$ 3

The results revealed that the incubation of the rat genitals in the presence of SNP increased the malondialdehyde contents (190\%). In contrast, the aqueous extract significantly reduced the MDA contents (160-25\%) of rats' penile and testicular homogenates. Moreover the magnitude of the decrease in malondialdehyde levels in response to the extract was significantly higher in the rats' penile homogenate (190\%-25\%) compared with the testis (190\%-58\%). Figure 2 revealed the interaction of the aqueous extract on arginase activity.

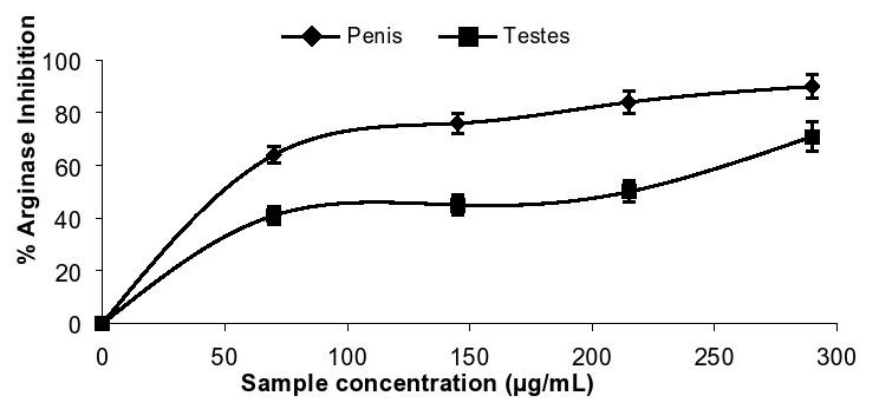

Fig. 2: Inhibition of arginase activity in rat's genitals by aqueous extract from Tetracarpidium conophorum leaves. $\mathrm{n}=3$

The extract decreased arginase activity in rats' penis and testes in a dose dependent manner. However the $\mathrm{IC}_{50}$ values in Table 1 revealed that the extract had a stronger inhibitory activity on penile arginase $(130.96 \mu \mathrm{g} / \mathrm{mL})$ than testicular arginase $(179.02$ $\mu \mathrm{g} / \mathrm{mL})$. 
Table 1: $\mathrm{IC}_{50}$ values of Inhibition of SNP-induced lipid peroxidation, $\mathrm{AChE}$, arginase and angiotensin -I converting enzyme activities in rat's genitals by aqueous extract of Tetracarpidium conophorum leaves.

\begin{tabular}{ccc}
\hline Parameters & Penis & Testes \\
\hline SNP $(\mathrm{mg} / \mathrm{mL})$ & $0.50 \pm 0.03^{\mathrm{b}}$ & $0.61 \pm 0.028^{\mathrm{b}}$ \\
Arginase $(\mu \mathrm{g} / \mathrm{mL})$ & $130.96 \pm 2.45^{\mathrm{c}}$ & $179.02 \pm 2.80^{\mathrm{d}}$ \\
AChE $(\mathrm{mg} / \mathrm{mL})$ & $0.58 \pm 0.01^{\mathrm{a}}$ & $0.47 \pm 0.03^{\mathrm{b}}$ \\
ACE $(\mu \mathrm{g} / \mathrm{mL})$ & $127.71 \pm 5.08^{\mathrm{d}}$ & $114.21 \pm 3.22^{\mathrm{e}}$ \\
\hline
\end{tabular}

Values represent mean \pm standard deviation, number of samples $n=3$. Values with the same superscript letter along the same row are not significantly ( $\mathrm{p} \leq$ $0.05)$ different.

Table 2: Phenolic constituents of aqueous extract from T. conophorum.

\begin{tabular}{cc}
\hline Parameters & Aqueous extract \\
\hline Gallic acid & $2.47 \pm 0.03$ \\
Catechin & $1.93 \pm 0.01$ \\
Chlorogenic acid & $6.71 \pm 0.01$ \\
Caffeic acid & $3.85 \pm 0.02$ \\
Coumarin & $6.79 \pm 0.02$ \\
Rutin & $1.90 \pm 0.01$ \\
Quercitrin & $10.47 \pm 0.03$ \\
Quercetin & $10.28 \pm 0.01$ \\
Kaempferol & $1.89 \pm 0.02$ \\
Luteolin & $12.56 \pm 0.01$ \\
\hline
\end{tabular}

Results are expressed as mean \pm standard deviations (SD) of three determinations. Source (Akomolafe, Oboh, Akindahunsi and Afolayan 2015)

The result of the inhibition of AChE activity as shown in Figure 3 revealed that the extract inhibited $\mathrm{AChE}$ activity in a dose-dependent manner $(0 \mathrm{mg} / \mathrm{mL}-1.2 \mathrm{mg} / \mathrm{mL})$. However, the extract had a higher inhibitory effect on penile AChE activity than that of the testes. Similarly, ACE inhibitory activity of the aqueous extract was assessed.

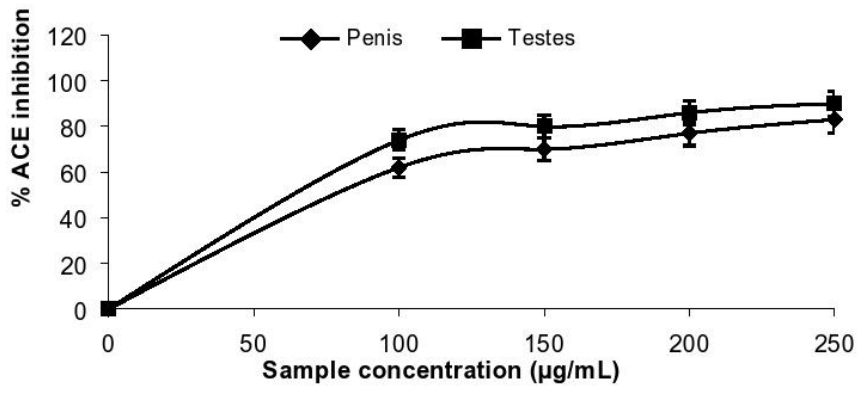

Fig. 3: Inhibition of angiotensin-I converting enzyme activity in rat's genitals by aqueous extract from Tetracarpidium conophorum leaves. $\mathrm{n}=3$

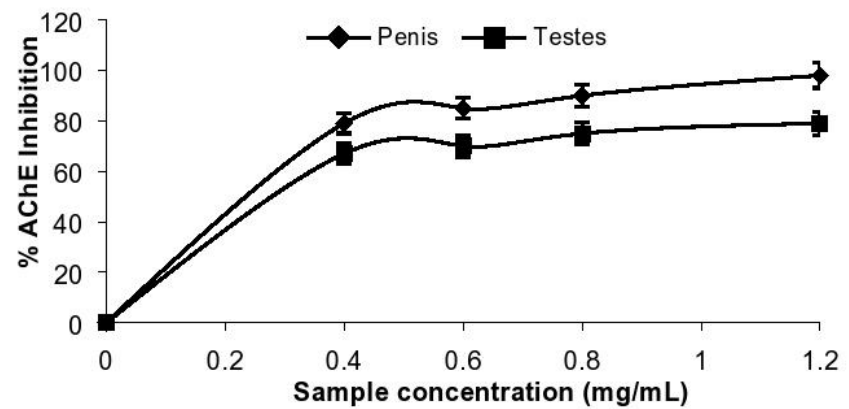

Fig. 4: Inhibition of acetylcholinesterase activity in rat's genitals by aqueous extract from Tetracarpidium conophorum leaves. $\mathrm{n}=3$

Figure 4 revealed that the extract inhibited penile and testicular ACE activities in a dose dependent manner $(0-250$ $\mu \mathrm{g} / \mathrm{mL})$. The $\mathrm{IC}_{50}$ values in Table 1 revealed that the inhibitory effect of the extract on penile $(127.71 \mu \mathrm{g} / \mathrm{mL})$ ACE activity was significantly $(\mathrm{P}<0.05)$ lower than the testes $(114.21 \mu \mathrm{g} / \mathrm{mL})$.

\section{DISCUSSION}

The result of this present study demonstrate for the first time the inhibitory effects of aqueous extract from $T$. conophorum leaves on SNP-induced lipid peroxidation and some enzymes linked to ED in vitro. Previous studies have shown that $\mathrm{NO}$ mediates the relaxation of smooth carvenosum via the guanyl cyclase/cGMP pathway which is an important pathway required for penile erection (Doshi et al., 2012). However, NO also influences ED due to the fact that low levels of NO impair the guanyl cyclase/cGMP pathway by competing with superoxides to form toxic peroxynitrites (Bivalacqua et al., 2003; Lee et al., 2008). Although peroxynitrites causes smooth muscle relaxation, it can also induce cell death in penile tissues via MDA production and decrease the bioavailability of NO (Oboh et al., 2015a; Agarwal et al., 2006). Our findings revealed that aqueous extract from $T$. conophorum was able to inhibit SNP-induced lipid peroxidation in penile and testicular homogenates. This indicates that the extract could prevent peroxynitrite-induced MDA production, oxidative damage and cell death to endothelial cells in the penile and testicular tissues. This also implies that NO will be bio-available to mediate the erectile process in ED patients. Previous result from our laboratory revealed that aqueous extract from $T$.conophorum contains phenolic acids such as caffeic acid, gallic acid, cholorogenic acid and flavonoids such as rutin, quercetin, quercitrin, kaempferol and luteolin (Akomolafe et al., 2015). These compounds are potent antioxidants and have been reported to scavenge NO radicals and inhibit lipid peroxidation (Oboh et al., 2015b; Kumar and Pandey, 2013).

Previous experimental investigations have also shown that NO production is linked to the regulation of arginase activity (Bivalacqua et al., 2001; Kim et al., 2009). Bivalacqua et al. (2003) reported that there is increased arginase activity in diabetic penile corpus cavernosum which connotes impairment in erectile response. However, decreased arginase activity in ED patients has been linked to vaso-relaxation of corpus cavernosum smooth muscle and increase in NO biosynthesis (Cox et al., 1999). Therefore inhibition of arginase activity could be a good therapeutic approach in the treatment and management of ED. Our findings revealed that aqueous extract from $T$. conophorum inhibited arginase activity in a dose dependent manner. Moreover, the observed inhibitory effects could be associated with the phenolic compounds present in the extract. This result is consistent with the report of Oboh et al. (2015a) on phenolic extracts from Moringa oleifera leaves which decreased arginase activity in penile tissues. Furthermore, Da Silva et al. (2012) and Dos Reis et al. (2013) reported that flavonoids such as catechins, quercetin, quercitrin and rutin which are present in the aqueous extract are potent inhibitors of arginase activity. The mechanism by which these compounds inhibit arginase activity is apparently via 
hydrogen bond formation and hydrophobic interactions with the amino acid residues present in the hydrophobic sites of the enzyme.

Experimental investigations using human and animal models have revealed that elevated levels of angiotensin II in the corpus cavernosum is associated with the development of ED (Becker et al., 2001a; Hamed et al., 2003). Jin (2009) reported that high levels of angiotensin II can induce increase in NADPH oxidase activity, ROS generation and inhibit endothelial nitric oxide synthase activity in penile tissues. Inhibition of nitric oxide synthase activity could further lead to low levels of NO, penile flaccidity, detumescence and rapid contraction of smooth muscle carvenosal cells (Jin, 2009; Park et al., 1997). Therefore blocking the formation of angiotensin II in penile and testicular corpus cavernosum could be beneficial in the treatment of ED. Inhibition of ACE activity is known to prevent the production of angiotensin II (Oboh et al., 2015b). Our results revealed that aqueous extract from $T$. conophorum inhibited ACE activity and could therefore reduce angiotensin II levels in rats' penis and testes. Meanwhile, the inhibitory effects of the extract may also prevent the degradation of bradykinin as this is common to ACE inhibitors (Jin, 2009). Bradynkinin is a potent stimulator of NO and has been implicated in erectile function (Becker et al., 2001b). It is interesting to note that inhibition of ACE in ED patients may have dual beneficial effects. The observed inhibitory effects could be linked to some phenolic compounds which have been identified in the extract in our previous report.

The aqueous extract from $T$. conophorum was further tested on AChE activity. AChE catalyses the break down of acetycholine in the cholinergic nerves of the corpus cavernosum smooth muscle cells and penile vasculature (Hedlund et al., 2000). Cholinergic nerves can influence erectile function by releasing acetylcholine in the corpus cavernosa cells (Jung et al., 2008; Saenz de Tejada et al., 1988). Acetylcholine released from the cavernous nerves is a potent vasodilator which mediates the relaxation of arteries that supply blood to the penile tissue (Jung et al., 2008). Increase in AChE activity disrupts the release of acetylcholine which leads to contraction of smooth muscles, penile detumescence, flaccidity and ED (Jung et al., 2008). This present study demonstrates the inhibitory effect of aqueous extract from $T$. conophonorum on AChE activity. The dose dependent inhibition of the enzyme in rats' penile and testicular tissue homogenates indicates that $T$. conophorum is a promising plant with therapeutic potentials for the treatment of ED.

\section{CONCLUSION}

Our findings revealed that aqueous extract from $\mathrm{T}$. conophorum inhibits SNP-induced lipid peroxidation, arginase, $\mathrm{ACE}$ and $\mathrm{AChE}$ activities in rats' penile and testicular tissue homogenates in vitro. This result suggests that the extract could improve penile and testicular endothelial cell function and restore erectile responses in patients with erectile dysfunction associated with oxidative stress. The observed inhibitory effects were linked to the phenolic acids and flavonoids that were identified in the extracts. Moreover, it will be interesting to isolate these compounds and determine their mechanism of actions using animal and human models.

\section{Financial support and sponsorship: Nil.}

Conflict of Interests: There are no conflicts of interest.

\section{REFERENCES}

Agarwal A, Nandipati KC, Sharma RK, Zippe CD, Raina R. Role of oxidative stress in the Pathophysiological mechanism of erectile dysfunction. J Androl, 2006; 27(3):335-347.

Akomolafe SF, Oboh G, Akindahunsi AA and Afolayan AJ. Tetracarpidium conophorum (Mull.Arg) Hutch \& Dalziel inhibits FeSO4 induced lipid peroxidation in rat's genitals. BMC Comp and Alt Med, 2015;15:57

Aminlari M. A Novel Colorimetric Method for Assaying Arginase Activity. Circulation, 1992; 25:431.

Andersson KE. Erectile physiological and pathophysiological pathways involved in erectile dysfunction. J Urol, 2003; 170:6 -14.

Andersson KE. Mechanisms of Penile Erection and Basis for Pharmacological Treatment of Erectile Dysfunction. Pharm Rev, 2011; 63: 811-859

Becker AJ, Ückert S, Stief CG, Scheller F, Knapp WH, Hartmann U, Jonas U. Plasma levels of angiotensin II during different penile conditions in the cavernous and systemic blood of healthy men and patients with erectile dysfunction. Urology 2001a; 58:805-10

Becker AJ, Ückert S, Stief CG, Truss MC, Machtens S, Scheller F, Knapp WH, Hartmann U, Jonas U. Possible role of bradykinin and angiotensin II in the regulation of penile erection and detumescence. Urology, 2001b;57:193-8.

Belle NAV, Dalmolin GD, Fonini G, Rubim MA and Rocha JBT. Polyamines Reduces Lipid Peroxidation Induced by Different Prooxidant Agents. Brain Research, 2004; 1008(2): 245-251.

Bivalacqua TJ, Hellstrom WGJ, Kadowitz PJ, Champion HC. Increased expression of arginase II in human diabetic corpus cavernosum: in diabetic-associated erectile dysfunction. Biochem Biophy Res Comm, 2001;283:923-927.

Bivalacqua TJ, Usta MF, Champion HC, Kadowitz PJ, Hellstrom WJ. Endothelial dysfunction in erectile dysfunction: role of the endothelium in erectile physiology and disease. J Androl, 2003; 24:1737

Botsoglou NA, Fletouris DJ, Papageorgiou GE, Vassilopoulos VN, Mantis AJ, Trakatellis AG. Rapid, sensitive and specific thiobarbituric acid method for measuring lipid peroxidation in animal tissue, food and feedstuff samples. J Agric Food Chem 1994; 42: 1931-37.

Cox JD, Kim NN, Traish AM, Christianson DW. Arginaseboronic acid complex highlights a physiological role in erectile function. Nature Struc Bio, 1999; 6:1043-1047

Cushman DW, Cheung HS. "Spectrophotometric assay and properties of the angiotensin-converting enzyme of rabbit lung," Biochem Pharm, 1971; 20(7):1637-1648,1971.

Da Silva, ER, Maquiaveli, CDC, Magalhaes PP. "The leishmanicidal flavonols quercetin and quercitrin target Leishmania (Leishmania) amazonensis arginase. Exp Parasitology, 2012;130(3):183$188,2012$.

Darley-Usmar V, White R. Disruption of vascular signaling by the reaction of nitric oxide with superoxide: implication for cardiovascular disease. Exp Phys, 1997; 82:305-16.

Dos Reis MBG, Manjolin LC, Maquiaveli CDC, Santos-Filho OA, da Silva ER. "Inhibition of Leishmania (Leishmania) amazonensis and rat arginases by green tea EGCG, (+)-catechin and (-)-epicatechin: a comparative structural analysis of enzyme-inhibitor interactions," PLoS ONE, 2013; 8 (78387):11. 
Doshi SB, Khullar K, Sharma RS, Agarwal A. Role of reactive nitrogen species in male infertility. Reproductive Bio and Endocrin, 2012; 10:109

Ferrini M, Magee TR, Vernet D, Rajfer J, Gonzalez-Cadavid NF. Agingrelated expression of inducible nitric oxide synthase and markers of tissue damage in the rat penis. Biology of Reprod, 2001; 64:974-982

Hamed EA, Meki AR, Gaafar AA, Hamed SA. Role of some vasoactive mediators in patients with erectile dysfunction: Their relationship with angiotensin converting enzyme and growth hormone. Int J Impotence Res, 2003; 15:418-25

Hedlund P, Ny L, Alm P, Andersson KE. Cholinergic nerves in human corpus cavernosum and spongiosum contain nitric oxide synthase and heme oxy-genase. J Urol, 2000; 164:868-875

Jeremy JY, Angelini GD, Khan M, Mikhailidis DP, Morgan RJ, Thompson CS, Bruckdorfer KR, Naseem KM. Platelets, oxidant stress and erectile dysfunction: an hypothesis. Cardiovascular Res, 2000; 46:50-54

Jin L. Angiotensin II Signaling and Its Implication in Erectile Dysfunction. J Sexual Med, 2009; 6(3):302-310

Jung J, Jo HW, Kwon H, Jeong NY. Clinical Neuroanatomy and Neurotransmitter-Mediated Regulation of Penile Erection. Int Neurourology J, 2014;18:58-62

Kim JH, Bugaj LJ, Oh YJ, Bivalacqua TJ, Ryoo S, Soucy KG, Santhanam L, Webb A, Camara A, Sikka G, Nyhan D, Shoukas AA, Ilies M, Christianson DW, Champion HC, Berkowitz DE. Arginase inhibition restores NOS coupling and reverses endothelial dysfunction and vascular stiffness in old rats. J Applied Phys, 2009; 107:1249-1257.

Kumar S, Pandey AK. Chemistry and Biological Activities of Flavonoids: An Overview. The Scientific World Journal, 2013; 162750: 16

Lee NP, Cheng CY. Nitric oxide and cyclic nucleotides: their roles in junction dynamics and spermatogenesis. Adv in Exp Med and Bio, 2008; 636:172-285

Oboh G, Ademiluyi AO, Ademosun AO, Olasehinde TA, Oyeleye SI, Boligon AA, Athayde ML. Phenolic Extract from Moringa oleifera Leaves Inhibits Key Enzymes Linked to Erectile Dysfunction and Oxidative Stress in Rats' Penile Tissues. Biochem Res Int, 2015a; 175950:8 doi.org/10.1155/2015/175950
Oboh G, Akinbola IA, Ademosun AO, Sanni DM, Odubanjo OV, Olasehinde TA, and Oyeleye SI. Essential Oil from Clove Bud (Eugenia aromatic Kuntze) Inhibit Key Enzymes Relevant to the Management of Type-2 Diabetes and Some Pro-oxidant Induced Lipid Peroxidation in Rats Pancreas in vitro. J Oleo Sci, 2015b; 64(7):775-782

Odugbemi O, Akinsulire O. Medicinal plants by species names in outlines and pictures of medicinal plants from Nigeria, T. Odugbemi, 2008 Ed., pp. 112, University of Lagos Presss, Lagos, Nigeria.

Park JK, Kim SZ, Kim SH, Park YK, Cho KW. Renin angiotensin system in rabbit corpus cavernosum: Functional characterization of angiotensin II receptors. J Urol, 1997; 158:653-8

Saenz de Tejada I, Blanco R, Goldstein I, Azadzoi K, de las Morenas A, Krane RJ, et al. Cholinergic neurotransmission in human corpus cavernosum. I. Responses of isolated tissue. Am J Physiol 1988;254:459-467

Subhashini N, Nagarajan G, Kavimani S. In vitro antioxidant and anticholinesterase activities of Garcinia combogia. Int $\mathrm{J}$ Pharm Pharmac Sci, 2011; 3(3):129-132.

Tor ER, Holstege DM, Galey FD. Determination of cholinesterase activity in brain and blood samples using a plate reader. $\mathrm{J}$ AOAC Int, 1994; 77:1308-1313.

\section{How to cite this article:}

Akomolafe S, Oboh G, Olasehinde T, Ogunsuyi O, Oyeleye S. Modulatory effects of Aqueous extract from Tetracarpidium conophorum leaves on key enzymes linked to erectile dysfunction and oxidative stress-induced lipid peroxidation in penile and testicular tissues. J App Pharm Sci, 2017; 7 (01): 051-056. 